\title{
Pengaruh Penggunaan Ampas Kecap dalam Ransum terhadap Kualitas Eksterior Telur Itik Mojosari
}

\author{
Influence Use of Soy Sauce By Product in The Range of Expander Quality of The Eggs of \\ Mojosari
}

\author{
B. Aminuddin, L. D. Mahfudz dan R. Muryani \\ Fakultas Peternakan dan Pertanian, Universitas Diponegoro, Semarang \\ Corresponding e-mail : Burhanaminuddin64@gmail.com
}

\begin{abstract}
The objective of this study was to examined the effect of soy sauce by product on exterior quality of duck eggs. The material used was 240 birds Mojosari duck at 20 weeks old with initial body weight of $1.385,0 \pm 130.85$ gram $(\mathrm{CV}=9.44 \%)$. The bird ingredients were rice bran, yellow corn, soybean meal, fish meal, pollard, premix and soy sauce by product. This research was used Completely Randomized Design (RAL) with 4 treatments and 6 replications total 24 experiment units, experiments and each unit consist of 10 birds. The treatment was soy sauce by product in the ration is as follows (T1: $0 \%, \mathrm{~T} 2: 5 \%, \mathrm{~T} 3: 7,5 \%$ and $\mathrm{T} 4: 10 \%)$. The parameters observed were the exterior quality of duck eggs which include: egg weight, eggshell thickness and eggshell weight. The data was analysed by analysis of variance (ANOVA) with $\mathrm{F}$ test to know effect of treatment. The results showed no significant difference on, egg weight, eggshell thickness and eggshell weight. Conclusion the soy sauce by product can be utilized in the diet of Mojosari duck until $10 \%$ without negatively affect to exterior quality of the egg.
\end{abstract}

Keywords: mojosari duck, soy sauce by product, external quality egg

\begin{abstract}
ABSTRAK
Penelitian bertujuan untuk mengkaji pengaruh penggunaan ampas kecap terhadap kualitas eksterior telur itik. Materi yang digunakan yaitu Itik Mojosari sebanyak 240 ekor dengan umur 24 minggu dengan berat badan awal rata - rata $1.385,0 \pm 130,85$ gram $(\mathrm{CV}=9,44 \%)$. Bahan penyusun ransum meliputi bekatul, jagung kuning, bungkil kedelai, tepung ikan, pollard, premix dan ampas kecap. Penelitian ini menggunakan Rancangan Acak Lengkap (RAL) dengan 4 perlakuan dan 6 ulangan sehingga ada 24 unit percobaan dan setiap unit ada 10 ekor itik. Perlakuan ampas kecap ke dalam ransum adalah sebagai berikut (T0 : $0 \%, \mathrm{~T} 1: 5 \%, \mathrm{~T} 2: 7,5 \%$ dan T3 : $10 \%)$. Parameter yang diamati adalah kualitas eksterior telur itik yang meliputi: berat telur, ketebalan cangkang telur dan berat cangkang telur. Analisis data menggunakan analisis ragam atau analisis of variance (ANOVA) dengan uji $\mathrm{F}$ untuk mengetahui pengaruh perlakuan. Hasil penelitian menunjukan tidak berbeda nyata, terhadap berat telur, ketebalan cangkang telur dan berat cangkang telur. Kesimpulan ampas kecap dalam ransum itik Mojosari sampai batas $10 \%$ dapat dimanfaatkan tanpa memberikan pengaruh negatif terhadap kualitas eksterior telur (berat telur, ketebalan cangkang telur dan berat cangkang telur).
\end{abstract}

Kata kunci : itik mojosari, ampas kecap, eksterior telur

\section{PENDAHULUAN}

Itik Mojosari merupakan itik lokal yang berasal dari desa Modopuro, Kecamatan Mojosari, Kabupaten Mojokerto, Jawa Timur. Itik Mojosari merupakan salah satu itik lokal yang memiliki produktivitas unggul sebagai penghasil telur. Meningkatnya pemeliharaan itik pada masyarakat menyebabkan kebutuhan pakan bagi ternak semakin meningkat sehingga menyebabkan harga pakan yang berkualitas menjadi mahal dan langka.

Ketersediaan pakan yang tidak memadai menyebabkan produktivitas dan kualitas dari telur menjadi menurun. Kualitas eksterior pada telur itik berkaitan dengan kekuatan cangkang dan penampilan cangkang menjadi preverensi konsumen dalam memilih telur. Upaya untuk meningkatkan kualitas eksterior telur yaitu dengan memberikan bahan pakan alternatif 
yang kaya akan kandungan protein dan mineral. Salah satu bahan pakan yang memiliki protein dan mineral yang baik adalah ampas kecap.

Ampas kecap mengandung protein sebesar 24,90\%; kalsium $0,39 \%$ dan fosfor 0,33\% (Widayati dan Widalestari, 1996). Kandungan mineral pada ampas kecap seperti kalsium dan fosfor dibutuhkan dalam proses pembentukan cangkang telur yang berpengaruh terhadap kualitas dari cangkang telur sebagai pelindung terluar dari telur. Penyerapan mineral oleh usus berkaitan dengan protein berupa mineral binding protein.

Kualitas eksterior telur dapat ditentukan dari kebersihan kulit, berat telur, kecacatan telur, warna cangkang telur, tebal cangkang telur serta kehalusan cangkang telur (Hintono, 1991). Faktor pakan yang sangat mempengaruhi besar telur adalah protein dan asam amino yang cukup dalam ransum dan asam linoleat (Wahju, 2004).

Ketebalan cangkang telur merupakan salah satu faktor yang mempengaruhi kualitas telur, karena cangkang dapat melindungi isi telur. Kekuatan cangkang sangat bergantung pada ketebalan cangkang telur yang dipengaruhi oleh genetik, nutrisi, penyakit dan temperatur lingkungan (Leeson dan Summers, 2001).

Tujuan dari penelitian yaitu untuk mengkaji pengaruh penggunaan ampas kecap yang telah dilakukan perendaman dalam larutan asam asetat 5\% dalam ransum dan diharapkan dapat memberikan pengaruh yang baik terhadap kualitas eksterior telur itik. Manfaat dari penelitian ini diharapkan mendapatkan informasi tentang penggunaan ampas kecap terhadap kualitas eksterior telur itik Mojosari.

Hipotesis dari penelitian ini adalah penggunaan ampas kecap dalam ransum dapat memberikan pengaruh yang baik terhadap kualitas eksterior telur itik yang dihasilkan.

\section{BAHAN DAN METODE}

Penelitian ini dilaksanakan pada tanggal 28 November 2016 - 28 Januari 2017 di Kandang Penelitian Universitas Darul Islam, Ungaran dan di Laboratorium Produksi Ternak Unggas, Departemen Peternakan, Fakultas Peternakan dan Pertanian, Universitas Diponegoro, Semarang dengan menggunakan itik Mojosari (Anas platyrnchos) sebanyak 240 ekor dengan umur 24 minggu dengan berat badan awal rata - rata 1.385,0 $\pm 130,85$ gram $(\mathrm{CV}=9,44 \%)$. Ampas kecap yang digunakan diperoleh dari limbah perusahaan kecap "Lele" di Pati.

Bahan penyusun ransum meliputi bekatul, jagung kuning, bungkil kedelai, tepung ikan, pollard, premix dan ampas kecap. Kandungan nutrisi bahan pakan dapat dilihat pada Tabel 1. Komposisi dan kandungan nutrisi ransum perlakuan ada pada Tabel 2.

Tabel 1. Kandungan Nutrisi Bahan Pakan

\begin{tabular}{|c|c|c|c|c|c|c|c|}
\hline \multirow{3}{*}{ No } & \multirow{3}{*}{ Bahan Pakan } & \multicolumn{6}{|c|}{ Kandungan nutrisi } \\
\hline & & EM & PK & LK & SK & $\mathrm{Ca}$ & $\mathrm{P}$ \\
\hline & & $(\mathrm{Kkal} / \mathrm{kg})$ & & & $-\%$ & & \\
\hline 1 & Kuning & $2785,32^{a}$ & $9,40^{\mathrm{a}}$ & $4,22^{\mathrm{a}}$ & $2,44^{\mathrm{a}}$ & $0,03^{\mathrm{b}}$ & $0,23^{\mathrm{b}}$ \\
\hline 2 & Tepung Ikan & $2091,40^{\mathrm{a}}$ & $37,33^{\mathrm{a}}$ & $5,18^{\mathrm{a}}$ & $2,31^{\mathrm{a}}$ & $12,08^{b}$ & $3,05^{\mathrm{b}}$ \\
\hline 3 & Bekatul & $3395,00^{\mathrm{a}}$ & $12,06^{\mathrm{a}}$ & $13,58^{\mathrm{a}}$ & $8,39^{a}$ & $0,32^{b}$ & $1,70^{\mathrm{b}}$ \\
\hline 4 & Pollard & $2587,10^{\mathrm{a}}$ & $13,46^{\mathrm{a}}$ & $0,70^{\mathrm{a}}$ & $4,48^{\mathrm{a}}$ & $0,09^{\mathrm{b}}$ & $0,78^{\mathrm{b}}$ \\
\hline 5 & Bungkil kedelai & $2985,05^{\mathrm{a}}$ & $42,84^{\mathrm{a}}$ & $3,00^{\mathrm{a}}$ & $1,90^{\mathrm{a}}$ & $0,24^{\mathrm{b}}$ & $0,57^{\mathrm{b}}$ \\
\hline 6 & Ampas Kecap & $3924,14^{\mathrm{a}}$ & $28,78^{\mathrm{a}}$ & $1,84^{\mathrm{a}}$ & $46,17^{\mathrm{a}}$ & $1,70^{\mathrm{a}}$ & $0,70^{\mathrm{a}}$ \\
\hline 7 & Premix & $959,43^{\mathrm{a}}$ & $5,26^{\mathrm{a}}$ & $4,23^{\mathrm{a}}$ & $3,35^{\mathrm{a}}$ & $3,30^{\mathrm{a}}$ & $3,50^{\mathrm{a}}$ \\
\hline
\end{tabular}

(a). Hasil Analisis Laboratorium Ilmu Nutrisi dan Pakan, Fakultas Peternakan dan Pertanian, Universitas Diponegoro, 2016. (b). Hartadi, 1997. 
Tabel 2. Komposisi dan Kandungan Nutrisi Ransum Perlakuan

\begin{tabular}{|c|c|c|c|c|}
\hline Susunan Ransum & T0 $(0 \%)$ & $\mathrm{T} 1(5 \%)$ & $\mathrm{T} 2(7,5 \%)$ & $\mathrm{T} 3(10 \%)$ \\
\hline Bahan Pakan : & \multicolumn{4}{|c|}{----------------------------------_\%--------------------------------- } \\
\hline Jagung Kuning & 41,70 & 40,60 & 41,00 & 39,70 \\
\hline Bekatul & 26,20 & 20,00 & 16,50 & 13,70 \\
\hline Bungkil Kedelai & 17,60 & 14,70 & 13,50 & 12,00 \\
\hline Tepung Ikan & 7,00 & 7,20 & 7,00 & 7,10 \\
\hline Pollard & 6,50 & 11,50 & 13,50 & 16,50 \\
\hline Premix & 1,00 & 1,00 & 1,00 & 1,00 \\
\hline Ampas Kecap & 0,00 & 5,00 & 7,50 & 10,00 \\
\hline Total & 100,00 & 100,00 & 100,00 & 100,00 \\
\hline \multicolumn{5}{|l|}{ Kandungan Nutrisi } \\
\hline Protein Kasar (\%) & 18,07 & 18,09 & 18,08 & 18,10 \\
\hline Lemak Kasar (\%) & 6,30 & 5,46 & 5,01 & 4,61 \\
\hline Serat Kasar (\%) & 4,04 & 5,97 & 6,91 & 7,90 \\
\hline Kalsium (\%) & 1,02 & 1,11 & 1,12 & 1,16 \\
\hline Fosfor $(\%)$ & 0,94 & 0,90 & 0,86 & 0,84 \\
\hline $\mathrm{EM}(\mathrm{kcal} / \mathrm{kg})^{2}$ & $2.900,00$ & $2.903,00$ & $2.905,00$ & $2.906,00$ \\
\hline
\end{tabular}

Sumber : Hasil Analisis Laboratorium Ilmu Nutrisi Pakan, Fakultas Peternakan dan Pertanian, Universitas Diponegoro, 2016.

Perlakuan yang diberikan yaitu berupa tingkat penggunaan ampas kecap dalam ransum yaitu $0 \%, 5 \%, 7,5 \%$ dan $10 \%$ (Tabel 2). Parameter yang diamati dalam penelitian ini yaitu kualitas eksterior telur itik yang meliputi berat telur, ketebalan cangkang telur dan berat cangkang telur. Rancangan percobaan yang akan digunakan dalam penelitian ini adalah Rancangan Acak lengkap (RAL), dengan 4 perlakuan dan 6 ulangan sehingga ada 24 unit percobaan, dimana setiap unit ada 10 ekor itik petelur. Data yang diperoleh dianalisis dengan menggunakan analisis ragam atau Analisis of Variance (ANOVA) dan uji F pada taraf 5\%. Jika terdapat pengaruh perlakuan, dilanjutkan dengan uji jarak berganda Duncan untuk mengetahui pengaruh perbedaan antara nilai tengah perlakuan.

\section{HASIL DAN PEMBAHASAN}

Hasil analisis data penelitian berupa berat telur itik, ketebalan cangkang telur itik, dan berat cangkang telur itik disajikan pada (Tabel 3).

\section{Pengaruh perlakuan terhadap berat telur itik mojosari}

Hasil analisis statistik (Tabel 3) menunjukan bahwa penggunaan ampas kecap dalam ransum tidak berpengaruh nyata $(\mathrm{P}>0,05)$ terhadap berat telur. Hal ini menunjukan bahwa penggunaan ampas kecap sampai taraf $10 \%$ dalam ransum tidak mempengaruhi berat telur. Hal ini disebabkan karena konsumsi protein setiap perlakuan hampir sama, sehingga dengan konsumsi protein yang sama akan menghasilkan berat telur yang tidak berbeda atau sama. Prasetyo et al (2006) menyatakan bahwa berat rata-rata telur itik Mojosari yaitu sebesar 60-65 gram/butir. Berat telur hasil penelitian lebih rendah karena itik yang digunakan masih berada pada masa awal produksi. Menurut Anggorodi (1995), faktor yang mempengaruhi berat telur adalah sifat genetik, umur, obat-obatan dan pakan. Kualitas pakan sangat berpengaruh dalam berat telur adalah protein dan asam amino, karena kurang dari $50 \%$ dari berat kering adalah protein. 
Tabel 3. Pengaruh perlakuan penggunaan ampas kecap dalam ransum terhadap berat telur, tebal cangkang dan berat cangkang.

\begin{tabular}{lrrrr}
\hline \multirow{2}{*}{ Variabel } & \multicolumn{5}{c}{ Perlakuan } \\
\cline { 2 - 5 } & T0 & T1 & T2 & T3 \\
\hline Berat telur $(\mathrm{g})$ & 59,17 & 57,83 & 58,75 & 58,96 \\
Tebal cangkang $(\mathrm{mm})$ & 0,30 & 0,30 & 0,32 & 0,30 \\
Berat cangkang $(\mathrm{g})$ & 8,17 & 7,88 & 7,92 & 8,33 \\
\hline
\end{tabular}

Tidak menunjukan perbedaan nyata $(\mathrm{P}>0,05)$

Hal ini sesuai dengan pendapat Wahju (2004), faktor yang sangat mempengaruhi berat telur yaitu protein dan asam amino yang cukup dan asam linoleat. Ransum dengan protein rendah akan menyebabkan pembentukan kuning telur menjadi kecil sehingga telur yang dihasilkan akan menjadi kecil dan sebaliknya. North dan Bell (1990) menyatakan ransum dengan kandungan protein tinggi dapat meningkatkan berat telur atau sebaliknya.

Umur akan mempengaruhi berat telur yang dihasilkan, semakin tua umur itik maka akan semakin berat pula telur yang dihasilkan. Menurut North dan Bell (1990) berat telur akan bertambah seiring dengan bertambahnya umur. Berat telur itik Mojosari yang digunakan lebih baik dari penelitian yang dilakukan Prasetyo dan Susanti (2000) yang menyatakan bahwa berat telur pada umur pertama bertelur itik Mojosari yaitu sebesar 53,69 gram dengan berat itik sebesar 1.161 gram.

Berat telur itik bergantung pula pada konsumsi ransum. Itik yang mengkonsusmi ransum lebih tinggi akan menghasilkan berat telur yang tinggi pula dan sebaliknya. Penggunaan ampas kecap dalam ransum sampai level $10 \%$ tidak memberikan pengaruh yang nyata terhadap berat telur, diduga itik tidak mengkonsusmsi asam amino esensial dalam jumlah yang rendah. Wahyu, (2004) menyatakan bahwa konsumsi ransum dipengaruhi oleh zat makanan yang terkandung dalam ransum. Akbarillah et al (2010) menambahkan pemberian jumlah pakan yang diberikan harus diperhatikan sehingga konsumsi pakan terjaga seimbang dan berat telur yang dihasilkan tidak menurun.

\section{Pengaruh perlakuan terhadap tebal cangkang telur itik mojosari}

Hasil analisis statistik (Tabel 3). menunjukan bahwa penggunaan ampas kecap dalam ransum tidak berpengaruh nyata $(\mathrm{P}>0,05)$ terhadap tebal cangkang. Widjaja (2001) menyatakan bahwa tebal cangkang telur yaitu berkisar antara $0,33 \mathrm{~mm}$ sampai 0,36 mm. Hal ini menunjukan bahwa penggunaan ampas kecap dalam ransum sampai taraf $10 \%$ dalam ransum tidak mempengaruhi tebal cangkang telur. Hal ini disebabkan karena kandungan kalsium dan fosfor pada setiap perlakuan tidak berbeda jauh dan sesuai dengan kebutuhan kalsim dan fosfor pada itik petelur yang menyebabkan kebutuhan dari kalsium dan fosfor terpenuhi dengan sama besarnya, walaupun konsumsi kalsium setiap perlakuan berbeda.

Kandungan $\mathrm{Ca}$ dan $\mathrm{P}$ dalam ransum berperan dalam menentukan kualitas cangkang telur karena dalam pembentukan cangkang telur diperlukan ion-ion $\mathrm{Ca}$ yang cukup untuk membentuk $\mathrm{CaCO} 3$ cangkang telur. Itik yang diberi ransum dengan kandungan kalsium tinggi akan menghasilkan cangkang telur yang tebal. Menurut Clunies et al (1992), semakin tinggi konsumsi kalsium maka kualitas cangkang telur akan semakin baik. Kualitas cangkang telur ditentukan oleh ketebalan dan struktur cangkang telur (Wahyu, 2004).

Kemampuan itik dalam mengabsorbsi kalsium yang tertimbun dalam matrik organik yang didalamnya mengandung protein dan mukopolisakarida. Bahan makanan yang dikonsumsi oleh unggas diperoleh dari matrik organik (Nuryadi, 2000). Hal ini juga secara fisiologis berpengaruh terhadap fungsi sistem 
pencernaan normal, absorbsi nutrisi terutama kalsium yang dapat dideposisikan pada pembentukan cangkang pada oviduk atau saluran telur sehingga ketebalan cangkang yang matriks utamanya terdiri dari senyawa kalsium. Leeson dan Summers (2001) menyatakanbahwa zat nutrisi utama yang mempengaruhi tebal cangkang telur adalah kalsium, fosfor dan vitamin D3.

\section{Pengaruh perlakuan terhadap berat cangkang telur itik mojosari}

Hasil analisis statisti (Tabel 3). menunjukan bahwa penggunaan ampas kecap dalam ransum tidak berpengaruh nyata $(\mathrm{P}>0,05)$ terhadap berat cangkang Juliambarwati et al (2012) menyatakan bahwa berat cangkang telur berkisar antara $9 \%$ sampai $12 \%$ dari total berat telur. Penggunaan ampas kecap dalam rasum sampai taraf $10 \%$ tidak dapat meningkatkan berat cangkang telur itik. Hal ini disebabkan karena ransum yang digunakan pada setiap perlakuan memiliki kandungan kalsium, energi, fosfor dan protein yang hampir sama. Selain itu kandungan mineral organik yang terdapat pada amps kecap terutama mineral kalsium (Ca) tidak dapat diserap dengan baik untuk pembentukan cangkang telur. Komposisi mineral tertinggi pada cangkang telur adalah mineral kalsium. Suprijatna et al (2008) menyatakan bahwa komposisi cangkang terdiri atas 98,2\% kalsium, 0,9\% magnesium dan $0,9 \%$ fosfor. Kalsium berperan dalam pembentukan cangkang telur (Amrullah, 2004).

Menurut Damayanti et al (2009), unggas yang diberikan pakan dengan kandungan kalsium tinggi, menghasilkan cangkang telur yang tebal sedangkan ketebalan cangkang akan berpengaruh terhadap berat cangkang. Faktor lain yang dapat mempengaruhi berat cangkang telur adalah besar telur yang dihasilkan. Karena telur yang ukurannya lebih besar, permukaan cangkangnya juga lebih luas, sehingga cangkang telur akan menjadi lebih berat. Menurut Clunies et al (1992) semakin tinggi $\mathrm{Ca}$ maka semakin tinggi juga berat maupun cangkang telur.

\section{KESIMPULAN}

Berdasarkan hasil penelitian, penggunaan ampas kecap dalam ransum dapat digunakan sampai level 10\% tanpa mempengaruhi kualitas eksterior telur.

\section{DAFTAR PUSTAKA}

Akbarillah, T., Kususiyah dan Hidayat. 2010. Pengaruh penggunaan daun indigofera segar sebagai suplemen pakan terhadap Produksi dan warna yolk itik. Jurnal Sain Peternakan Indonesia. 5 (1) : 27 33.

Amrullah, I. K. 2004. Nutrisi Ayam Petelur. Lembaga Satu Gunungbudi, Bogor.

Anggorodi, R. 1995. Nutrisi Aneka Ternak Unggas. Gramedia. Jakarta.

Clunies. M., D. Parks dan S. Lesson. 1992. Colocium and Phosphorus metabolism and egg shell Formation of hans Fed Different Amounts of colocium. Poultry. 71: 482-489.

Damayanti, E., A. Sofyan., H. Julendra dan T. Untani. 2009. Pemanfaatan tepung cacing tanah (Lumbricus rumbellus) sebagai agensia Anti-Pullorum dalam imbuhan pakan ayam broiler. Fakultas Kedokteran. Universitas Gadjah Mada. Yogyakarta.

Hartadi, S. 1997. Tabel Komposisi Pakan untuk Indonesia. UGM Press. Yogyakarta.

Hintono, A. 1991. Pengendalian kualitas telur pada paska produksi. Poultry Indonesia $140: 22-24$.

Juliambarwati, M., R. Adi dan H. Aqni. 2012. Pengaruh penggunaan tepung limbah udang dalam ransum terhadap kualitas telur itik. Universitas Sebelas Maret. Surakarta. Sains Peternakan. 10 (1) : $1-6$. 
Leeson, S. and J.D. Summers. 2001. Nutrition of the Chicken. University Book, Canada.

North, M. O. and D. D. Bell. 1990. Commercial Chicken Production Manual. Avi Publishing Company Inc. Westport, Connecticut.

Nuryadi, D. R. 2000. Dasar-Dasar Reproduksi Ternak. Universitas Brawijaya. Malang.

Prasetyo, L. H. dan T. Susanti. 2000. Persilangan timbal balik antara itik Alabio dan Mojosari: Periode Awal Bertelur. Jurnal Ilmu Ternak dan Veteriner 10 (2): 210 - 214.

Prasetyo, L.H., Susanti, T dan M. Purba. 2006. Kualitas telur itik Alabio dan
Mojosari pada generasi pertama populasi seleksi. Prosiding Seminar Nasional Teknologi Peternakan dan Veteriner. 2016. Puslitbang Peternakan, Bogor. 687 - 693.

Suprijatna, E., A. Umiyati. dan Ruhyat, K. 2008. Ilmu Dasar Ternak Unggas. Penebar Swadaya, Jakarta. Cetakan II.

Wahju. 2004. Ilmu Nutrisi Unggas. Universitas Gajah Mada Press, Yogyakarta.

Widayati, E. dan Y. Widalestari. 1996. Limbah untuk Pakan Ternak. Trubus Agrisarana. Surabaya.

Widjaja, H. 2001. Seandainya Telur Bisa Bicara. Poultry Indonesia. 44-46. 